\title{
PENGAJARAN ILMU HUKUM DALAM KELAS MODEL/ \\ KREASI PEMBELAJARAN MENGHUBUNGKAN TEORI \\ DENGAN INFO-INFO PERISTIWA HUKUM "PIDANA" \\ DARI MEDIA CETAK \\ (Analisis Studi Kepuasan)
}

\section{Hamsir}

Fakultas Syariah dan Hukum Universitas Islam Negeri Alauddin Makassar

\begin{abstract}
Print media as a source of info on legal phenomena that occur in society is very important in the development of criminal law teaching in classes in law studies. The form / model of learning found in lectures in Islamic law and state administration has an impact on the enthusiasm of students in the lecture process. In addition, it establishes and builds knowledge of scientific interconnections between criminal law, criminology and legal sociology for students.
\end{abstract}

\section{Keywords:}

Print Media, Legal Cases, Learning Processes

\begin{abstract}
Abstrak
Media cetak sebagai sumber info fenomena-fenomena hukum yang terjadi di masyarakat menjadi sangat penting dalam pengembangan pengajaran ilmu hukum pidana di dalam kelas-kelas perkuliahan ilmu hukum. Bentuk/model pembelajaran tersebut yang ditemukan pada perkuliahan ilmu hukum dan ketatanegaraan Islam berdampak pada antusiasme mahasiswa dalam proses perkuliahan. Di samping itu, membentuk dan membangun pengetahuan akan interkoneksi keilmuan antara ilmu hukum pidana, kriminologi dan sosiologi hukum bagi mahasiswa.
\end{abstract}

Kata Kunci:

Media Cetak, Kasus Hukum, Proses Pembelajaran

\section{A. PENDAHULUAN}

ebelum membahas dalam beberapa sub bahasan masalah, maka terlebih dahulu diberi beberapa pengertian dalam judul tersebut, yakni dengan judul pengajaran ilmu hukum dalam kelas dengan analisis kepuasan atas model/kreasi pembelajaran dengan menghubungkan teori dengan info-info peristiwa hukum "Pidana" dari berita media cetak (harian fajar).

Dari judul di atas tentang model pengajaran dalam kelas, tentunya yang 
dibayangkan adalah suatu hal yang sudah hal biasa " sudah klassik" dilakukan oleh banyak pihak pendidik "dosen". Namun karena ada suatu kreasi yang menyertainya, berupa pemakaian atau menggunakan alat bantu atau materi bantu sebagai bentuk kreativitas, yakni dengan menggunting atau menyiapkan klipping koran yang berisi berita-berita hukum keseharian di suatu media "harian fajar" yang relevan dengan pembahasan materi ajar dalam sillaby dan tersusun berdasarkan sillaby dan atau kontrak persemester

Penelitian yang dilakukan oleh dosen tersebut dengan memakai alat bantu, bahan bantu atau alat peraga dari guntingan-guntingan koran (harian fajar) yang memuat berita-berita aktual hukum, kriminal dan sosial yang beraspek hukum.

Obyek penelitian ini ditekankan pada dua aktifitas, obyek dosen selaku pencipta model/kreasi dan subyek mahasiswa yang dikenai sasaran model/kreasi dosen dengan memakai alat bantu atau bahan bantu materi ajar atau sebagai alat peraga yakni guntingan berita-berita hukum di koran fajar, baik yang masih aktual maupun yang sudah tidak aktual, tetapi masih relevan .

Penelitian ini menjadi menarik dan penting karena sudah sekian lama dipraktekan, olehnya peneliti menelusurinye dengan mengamati beberapa sikap atau respon beberapa mahasiswa tersebut selama dipraktekkannya model/ kreasi dosen tersebut, namun tidak ada penolakan akan kreasi/model tersebut . Kemudian menelususri pula dosen yang bersangkutan yang saat ini masih tetap memperahankan menggunakan model/kreasi tersebut.

Penelitian ini pula menelususri, dasar pijakannya, yakni kurikulum dan turunannnya pada silabus/sillaby atau kontrak materi ajar selama semester berjalan . Dari dasar pijakan kurikulum, seperti di bawah ini, berupa kurikulum program studi ilmu hukum yang memuat mata-mata kuliah ilmu yang amat berkesesuaian dengan model/kreasi, yang antara lain, mata kuliah hukum pidana, hukum acara pidana, delik-delik di luar KUHP, hukum acara PTUN sosiologi hukum dan mata-mata kuliah lainnya yang dalam prakteknya banyak bersentuhan dengn kehidupan seharihari masyarakat.

Sebagai gambaran kurikuluam di bawah ini pada fakultas syariah dan hukum, maka peneliti hanya mengambil satu sampel kurikulim tahun 2008 prodi, yakni Prodi Ilmu Hukum

\section{B. PEMBAHASAN}

Perintah mencerdaskan kehidupan bangsa khususnya anak didik mahasiswa" dilingkungan perguruan tinggi, adalah perintah konstitusi dan perundangan, UUD 1945, Pasal 31 ayat 3, bahwa Negara mengusahakan dan menyelenggarakan sistem pendidikan dalam rangka mencerdaskan, tegasnya seperti diatur dalam pasal 1 ayat 3 Undng Undang Nomor 20 Tahun 2003, bahwa pendidikan nasional adalah " suatu sistem keseluruhan dan komponen yang terpadu untuk mencapai tujuan pendidikan 
nasional , "membuat mereka pandai" ${ }^{1}$.

Sistem Pendidikan Nasional yang merupakan rangkaian kesatuan yang tidak terpisahkan dari model nasional yang ada. Perguruan tinggi sebagai bagian dari suatu sistem pendidikan nasional dan sebagai suatu sub sistem pendidikan yang berada pada level akhir (tertinggi , S1, S2, S3).

Khususnya di Indonesia ketentuan tentang perguruan tinggi telah diatur dalam Undang Undang Nomor 12 Tahun 2012, tentang tugas, hak dan kewajiaban PT, sebagai salah satu penyelenggara pendidikan nasional, tentunya berpayung pada amanah konstitusi negara Republik Indonesia, yakni UUD 1945 Pasal 31 yang dalam salah satu isi pasal dalam pasal tersebut yakni Negara mengusahakan dan menyelenggarakan sistem penddikan dalam rangka mencerdaskan bangsa.

Kata pendidikan dalam pasal 31 UUD 1945 tersebut dipertegas dalam UU No. 12 Tahun 2012 dalam pasal 1 ayat 1 ,

"Bahwa pendidikan adalah usaha sadar dan terencana yang mewujudkan sistem belajar dan proses pembelajaran agar peserta didik secara aktif mengembangkan potensi dirinya untuk memiliki kekuatan spiritual, keagamaan, pengendalian diri, kepribadian, kecerdasan, akhlak mulia serta keterampilan yang diperlukan dirinya, masyarakat, bangsa dan negara. ${ }^{2}$

Dalam berjalannya sistem pelaksanaan tugas dosen PA, hal mana figur dosen atau guru atau pendidik bagi anak didiknya dalam hal ini mahasiswa atau objek anak didik di PTm sehingga Figur dosen bagi mahasisiwa, seperti kata Robert Fisher, bahwa anak didik/ mahasiswa senantiasa adalah pengembara di negeri "PT" penuh misteri " dan kita "dosen/guru" sebagai penunjuknya. ${ }^{3}$

Seperti pula yang dinyatakan dalam pasal 3 UU Sisdiknas No.20 tahun 2003, bahwa fungsi pendidikan untuk mengembangkan kemampuan dan membentuk watak serta peradaban bangsa bermartabat dalam rangka mencerdaskan kehidupan bangsa yang bertujuan megembangkan potensi peserta didik agar menjadi manusia yang beriman dan bertaqwa kepada Tuhan Yang Maha Esa, barakhlak mulia. Berilmu, cakap, kreatif, mandiri dan menjadi warga negara yang demokratis serta bertanggung jawab.

Dalam pembukaan Undang Undang Dasar Republik Indonesia 1945, menyatakan bahwa:

"Tujuan nasional adalah untuk melindungi segenapa bangsa dan seluruh tumpah darah Indoneia dan memajukan kesejahteraan umum, mencerdaskan kehidupan bangsa dan ikut melaksanakan ketertiban dunia berdasarkan kemerdekaan, perdamaian abadi dan keadilan sosial." ${ }^{4}$

\footnotetext{
${ }^{1}$ UU No.20 Tahun 2003, Tentang Ssistem Pendidikan Nasional, Laksana, Jogyakarta, 2003, h, 5.

${ }^{2}$ Undang-Undang No, 12 Tahun 2012, Harvarindo, Jakarta, h, 3.

${ }^{3}$.Ngainun N, Menjadi Guru Insfiratif, Putaka Pelajar, Jogyakarta, 2011, h, 171

4 Rahman Getteng, Menuju Guru Professional dan Beretika (lampiran UUD 1945) Graha Guru, Yogyakarta, 2012, h, 141
} 
Dalam UU No.12 tahun 2012 Pasal 1 ayat 14 Bab 1 ketentuan umum,serta pasal 12 , bahwa dosen adalah

"pendidik pofesional \& ilmuwan dengan tugas utama mentransformasikan, mengembankan dan menyebarluaska ilmu pengetahuan dan teknologi melalui pendidikan, penelitian dan pengabdian masyarakat. Serta dosen mendorong mahasiswa atau mendorong potensi diirnya (mahasiswa)" 5

Dalam UU tentang Guru dan Dosen No. 14 Tahun 2005 dijelaskaan bahwa: "Guru "dosen" adalah pendidik professional dengan tugas utama mendidik, mengajar, membimbing ( $\mathrm{ta}^{\prime} \mathrm{lim}$ ) mengarahkan, melatih, menilai dan mengevaluasi peserta didik ...". Olehnya mengajar sebagai pekerjaan profesional.

Wina Sanjaya (2008)mengemukakan ciri-ciri dan karakteristik tugas profesional seorang guru dan dosen, antara lain:

"bahwa menjadi guru/dosen bukan hanya cukup memahami materi yang harus disampaikan, akan tetapi juga diperlukan kemampuan dan pemahaman tentang pengetahuan tentang psikologi perkembangan manusia, mampu mengembangkan minat dan bakat serta potensi ${ }^{6}$

Kaitan dengan kreasi atau model pembelajaran/pemberian materi ajar yang menjadi tujuan pokok penelitian ini, tentunya relevan dengan Pasal 12 ayat 2 Surat Keputusan Rektorn UIN Alauddin Makassar Nomor;241 B tahun 2010 tentang Pedoman Edukasi UIN Alauddin Makassar, antara lain:

“(1). Memberi kesempatan bagi mahasiswa yang cakap dan giat belajar agar dapat menyelesaikan studi dalam waktu sesingkat-singkatnya. (2), Memberi kemungkinan agar sistem pembelajaran mampu menumbuhkan kreatifitas ilmiah secara luas dan mendalam, (3). Memberi kemungkinan agar sistem evaluasi kemajuan belajar mahasiwa dapat diselenggarakan lebih efektif dan terencana, (4). Memberi kemungkinan agar sistem pendidikan dan pengajaran yang dilakukan secara berimbang anatara mahasiswa yang masuk (input) dan mahasiswa yang telah lulus (output)",,

Perintah mencerdaskan anak didik "mahasiswa" seperti yang telah dikemukakan di atas, secara praktis pada umumnya para dosen/pendidik telah melaksanakan, namun barulah sebatas model pencerdasan model lama yang telah kuno dan klassik. Namun ada juga sebagian kecil beberapa dosen khususnya di gfakultas syariah dan hukum, telah meninggalkan model lama dan klassik tersebut, dengan beralih memakai metode lain, misalnya memakai media surat kabar sebaagai sumber, wadah dan peraga dalam memberikan pengajaran/asupan kepada anak

${ }^{5}$ UU No.12 Tahun 2012 tentang Sistem Pendidikan Nasional, Harvarindo, Jakarta, 2013 , Jakarta, h, 3 -

8.

${ }^{6}$ Rahman Getteng, Menuju Guru Professional dan Beretika, Graha Guru, Jogyakarta,2012, h, 10-11

7 Kumpulan Peraturan Akademik 2010, Biro Administrasi Akademik dan Kemahasiswaan UIN, Makassar, 2010 
didiknya "mahasiswa".

Model tersebut tentunya tetap merujuk pada struktur birokrasi dan instrumen administrasi akademik, dimana sumber media suratkabar "fajar" yang berbentuk kliping yang memuat berita-berita, ulasan ilmiah, populer dan semi ilmiah populer tentang peristiwa hukum aktual dan yang semasih relevan. Keseluruhan isi klipping korang tersebut adalah merupakan isi dari salah satu sampai tiga mata kuliah yang tertera dalam kurikulum, misalnya mata hukumpidana 1, hukum acara pidana dan soiologi hukum.

Turunan dari beberapa mata kuliah yang ada dalam kurikulum tersebut, yaitu sillabus/sillaby yang merupakan pokok-pokok bahasan Isi materi kuliah setiap kali pertemuan. Hal mana umumnya isi pokok bahasan permata kuliah tersebut tentunya dominan atau hanyalah berisi tentang, teori-teori, pengertian, asas-asas dan prinsip akan suatu ilmu pengetahuan, misalnya pengertian hukum pidana, teoriteori hukum pidana, asas-asas, prinsip-prinsip serta kaidah-kaidah/pasal-pasal perundang-undanganya hukum pidana.

Adapun tentang contoh-contoh atau praktek-praktek hukum pidana yang riel, baik yang telah terjadi di masyarakat, maupun harapan yang akan terjadi di tengahtengah masyaraka, buku-buku teks ajar tentang hal itu sangatlah sedikit, sudah sangat kuno, klassik dan membosankan dan terkadang tidak aktua; lagi.

Oleehnya media suratkabar yang berbentuk klipping sangat membantu memahami semakin mudah memahami teks-teks teori yang ada, karena seketika pengajar/dosen "hukum pidana" yang bersangkutan telah menyiapkan sebuah info, berita ataupun ulasan hukum dalam klipping yang diambil dari surat kabar "fajar' tentunya berita-berita dari peristiwa hukum keseharian sampai pada berita hukum yang temporer/canggih. Hal tersebut menjadi menarik dan tidak membosankan karena setiap kali (seminggu pertemuan) dengan pokok pembahasan yang berbeda, tentunya berita-berita atau ulasan hukum dari klipping koran yang berbeda pula.

Adapun teknis penyusunan pokok bahasan dan dirangkaikan dengan sebuah berita klipping koran yang terkait pokok pembahasan setiap kali perkiuliahan, Misalnya:

Pokok pembahasan (I) tentang pengertian dan pendefenisian hukum pidana, maka berita-berita atau ulasan-ulasan hukum, berupa fakta-fakta berita yang terkadi dalam rangkaian untuk poko bahasan pengertian dan pendefesian hukum pidana.

Dalam kontrak pertemuan pertama (I) seperti yang tertera dalam kontrak sillaby di atas, maka yang akan dibahas sebagai pokok bahasan tersebut adalah Pengertian dan pendefenisian Hukum Pidana. Maka ada baiknya membaca dan mendiskusikan dan menjelaskan prihal apa yang pernah ditulis dalam suatu media "harian fajar kolom hukum \& 1001 masalah kemasyarakatan", oleh Prof. Ahmad Ali, SH, MH (Alm).pada tahun 2010. (klipping berita terlampir)

Dalam kontrak pertemuan kedua (II) seperti yang tertera dalam kontrak sillaby di atas, maka yang akan dibahas dalam pokok bahasan tersebut adalah 
PengertianRuang lingkup serta kekuatan berlakunya hukum pidana. Maka ada baiknya membaca dan mendiskusikan dan menjelaskan prihal apa yang pernah ditulis dalam suatu media "harian fajar kolom hukum \& 1001 masalah kemasyarakatan", oleh Prof. Ahmad Ali, SH, MH (Alm).pada tahun 2010. (klipping berita terlampir)

Dalam kontrak pertemuan ketiga (III) seperti yang tertera dalam kontrak sillaby di atas, maka yang akan dibahas dalam pokok bahasan tersebut adalah Pengertian hukum pidana materiel dan hukum pidana formiel. Maka ada baiknya membaca dan mendiskusikan dan menjelaskan prihal apa yang pernah ditulis dalam suatu media "harian fajar kolom hukum \& 1001 masalah kemasyarakatan", oleh Prof. Ahmad Ali, SH, MH (Alm).pada tahun 2010. (klipping berita terlampir)

Dalam kontrak pertemuan ke empat (IV) seperti yang tertera dalam kontrak sillaby di atas, maka yang akan dibahas dalam pokok bahasan tersebut adalah Pengertian Ebentuk hukum pidana materiel. Maka ada baiknya membaca dan mendiskusikan dan menjelaskan prihal apa yang pernah dimuat dalam harian fajar, kamis 8 Nopember 2012 . (klipping berita terlampir)

Dalam kontrak pertemuan ke lima (V) seperti yang tertera dalam kontrak sillaby di atas, maka yang akan dibahas dalam pokok bahasan tersebut adalah Pengertian $\mathcal{E}$ bentuk hukum pidana formiel. Maka ada baiknya membaca dan mendiskusikan dan menjelaskan prihal beberapa hal berita-berita hukum yang terkait pelaksanaan hukum pidana formiel serta tulisan kolom oleh Prof Ahmad Ali SH (Alm) dimuat dalam harian fajar 2010-2012 . (klipping berita terlampir)

Dalam kontrak pertemuan keenam (VI) seperti yang tertera dalam kontrak sillaby di atas, maka yang akan dibahas dalam pokok bahasan tersebut adalah Keadilan dan sanksi dalam hukum pidana. Maka ada baiknya membaca dan mendiskusikan dan menjelaskan prihal apa yang pernah ditulis dalam suatu media "harian fajar kolom hukum \& 1001 masalah kemasyarakatan", ulasan oleh Prof. Ahmad Ali, SH, MH (Alm).2010 ,Dr.Zainuddin, Sag, SH. MH , serta berita hukum lainnya "harian Fajar 20-2-2012" (klipping berita terlampir)

Dalam kontrak pertemuan ke tujuh (VII) seperti yang tertera dalam kontrak sillaby di atas, maka yang akan dibahas dalam pokok bahasan tersebut adalah Pengertian $\mathcal{E}$ bentuk kejahatan dalam Hukum Pidana dan dalam KUUHP . Maka ada baiknya membaca dan mendiskusikan dan menjelaskan prihal apa yang pernah dimuat dalam harian fajar, kamis 8 Nopember 2012 serta ulasan hukum Prof . Dr. Ahmad Ali, SH. (Alm.) dalam kolom 1001 hukum harian fajar 2012 (klipping berita terlampir)

Dalam kontrak pertemuan ke delapan (VIII) seperti yang tertera dalam kontrak sillaby di atas, maka yang akan dibahas dalam pokok bahasan tersebut adalah Pengertians bentuk pelanggaran dalam hukum pidana. Maka ada baiknya membaca dan mendiskusikan dan menjelaskan prihal apa yang pernah dimuat dalam harian fajar, jumat 9 Maret 2012 . (klipping berita terlampir) 
Dalam kontrak pertemuan ke sembilan ( IX) seperti yang tertera dalam kontrak sillaby di atas, maka yang akan dibahas dalam pokok bahasan tersebut adalah Pengertian ius konstitutum dan ius konstituendumdalam hukum pidana. Maka ada baiknya membaca dan mendiskusikan dan menjelaskan prihal apa yang pernah dimuat dalam kolom 1001 hukum "fajar" oleh Prof Ahmad Ali, SH tahun 2009-2012 (klipping berita terlampir)

Dalam kontrak pertemuan ke sepuluh ( $X$ ) seperti yang tertera dalam kontrak sillaby di atas, maka yang akan dibahas dalam pokok bahasan tersebut adalah Pengertian kejahatan dilakukna secaran individu dan secara turut serta dan atau secara bersama-sama, maka ada baiknya membaca dan mendiskusikan dan menjelaskan prihal apa yang pernah dimuat dalam berita harian fajar tanggal 15-22012 (klipping berita terlampir)

Dalam kontrak pertemuan ke sebelas (XI) seperti yang tertera dalam kontrak sillaby di atas, maka yang akan dibahas dalam pokok bahasan tersebut adalah Pengertian delik aduan dan delik biasa dalam hukum pidana, maka ada baiknya membaca dan mendiskusikan dan menjelaskan prihal apa yang pernah dimuat dalam berita harian fajar tahun 2013 (klipping berita terlampir)

Dalam kontrak pertemuan ke dua belas (XII) seperti yang tertera dalam kontrak sillaby di atas, maka yang akan dibahas dalam pokok bahasan tersebut adalah Pengertian dan bentuk delik- delik di luar kitab undang-undang hukum pidana (KUUHP), maka ada baiknya membaca dan mendiskusikan dan menjelaskan prihal apa yang pernah dimuat dalam berita harian fajar tahun 2013 (klipping berita terlampir)

Dalam kontrak pertemuan ke tigabelas ( XIII) seperti yang tertera dalam kontrak sillaby di atas, maka yang akan dibahas dalam pokok bahasan tersebut adalah Pengertian Daluarsa dalam hukum dan KUUHPidana, maka ada baiknya membaca dan mendiskusikan dan menjelaskan prihal apa yang pernah dimuat dalam sutu ulasan lengkap dalam tulisan Prof Ahmada Ali, SH, harian fajar tahun 2011 (klipping berita terlampir)

Dalam kontrak pertemuan ke empat belas( XIV) seperti yang tertera dalam kontrak sillaby di atas, maka yang akan dibahas dalam pokok bahasan tersebut adalah Tindak pidana Islam dan pidana positif dalam sanksi pemberatan pemerkosaan serta hukuman mati, maka ada baiknya membaca dan mendiskusikan dan menjelaskan prihal apa yang pernah dimuat dalam sutu ulasan lengkap dalam tulisan Prof .DR. Ahmad Ali, SH, (Alm) harian fajar 12 januari 2005

Harian fajar sebagai suatu media yang terbit di Makassar memuat berbagai hal dan peristiwa, sosial, budaya, ekonomi, hukuum, kemanan dan pertahanan dalam negara. Menelususri berita-berita, peristiwa dan ulasan-ulasan hukum pidana baik secara teoretik terlebih dalam praktek dilakukan sejak tahun 2008-2014.

Pada prinsipnya normatif hukum pidana, berupa unsur-unsur suatu perbuatan pidana serta sanksi pidana, menyangkut khususnya perbuatan kejahatan, relatif 
bersifat permanen, rigid dan kaku, sehingga semua peristiwa kejahatan yang terjadi baik yang klassik maupun yang temporer, hampir semuanya dapat diselesaikan oleh perundang-undangan yang ada mekipun telah sekian lama di buat (kecuali kejahatan-kejahatan temporer, yang melahirkan aturan deliknya ada di luar KUUHPidana).

Adapun peristiwa yang diatur dalam wadah aturan yang bersifa $t^{\prime \prime}$ bukan kejahatan" , tetapi dibuat demi untuk kepentingan manusia saat itu, kondisi dan keadaan itu menghendaki, maka ranahnya di buat dalam aturan yang sanksinya disebut pelanggaran, sehingga aturan dan sanksinya dapat berubah seketika datau berahan lama sesuai kepentingan masyarakatnya.

Keterangan sebuah media menyangkut informasi peristiwa hukum, umunmya, beritanya sebatas pada peristiwa terjadinya dan sangat jarang media menginfokan akhir dari sanksi suatu peristiwa hukum (kejahatan ataupun pelanggaran) kecuali bila obyek dan pelakunya adalah bersifat meluas dan menimpa orang tertentu "terkenal/tokoh/selebriti" dan sebagainya.

Olehnya sesungguhnya di situlah hukum dapat dipelajari lebih mendalam dan hal itu, sangat langka dikemukakan di media, kecuali bila peristiwa dan obyeknya tertentu dan atau amat berbeda dengan peristiwa hukum lainnya.

Dengan menghubungkan teori dasar yang sudah atau sementara diajarkan atau dengan memparalelkan teori dan praktek yang terjadi yang telah dimuat dalam suatu media "harian fajar", misalnya, ketentuan normatifnya suatu pengetahuan hukum yang diajarkan oleh dosen kemudian dihubungkan dengan info-info suatu peristiwa hukum yang terjadi di tengah-tengah masyarakat yang bersumber dari terbitan media (surat kabar harian Fajar) yang aktual.

Dari hasil penelitian dengan merujuk pada acuan pada tiga (3) pokok bahasan yang telah dikemukakan di atas, maka penulis dapat mendeskripsikan hasil yang ada, yang antara lain. bahwa:

Secara tersurat tentang keharusan model pembelajaran suatu materi ilmu pengetahuan khusus di depan kelas menurut aturan peruandangg-undangan dan konstitusi yang, hal tersebut tidak secara teknis dijelaskan, dan diuraikan, Namun secara secara prinsip-prinsip perintah perundang-undangan serta konstitusi yang ada, dapat dipahami. Bahwa pada prinsipnya anak didik dalam kelas adalah bagian kelompok sumber daya manusia (SDM) yang harus diberi kemampuan oleh negara melalui perguruan tingggi untuk dididik menjadi bagian kecil dari masyarakat negara Indonesia yang berusia muda yang biasa disebut mahasiswa untuk dijadikan kelak menjadi orang yang berilmu pengetahuan, berimam dan bertaqwa. Artinya mahasiswa diberi asupan pengetahuan oleh dosen selaku pendidik atas perintah negara dalam wadah yang bernama perguruan tinggi "universitas", seperti yang tercantum dalam tujuan pendidikan di perguruan tinggi (Undang Undang Nomor 12 Tahun 2012) yakni terciptanya anak didik "mahasiswa" yang cerdas, mandiri, professional dan berakhlak mulia, artinya kelak memiliki sikap professional atas 
ilmu pengetahuannya sekaligus bergandengan dengan sikapnya sebagai seorang yang memiliki sikap-sikap keTuhanan, yang kelak ilmu pengetahuan yang dimiliki tidak hanya bertanggung-jawab disisi keduniaan tetapi juga bertanggung jawab di hadapan Tuhannya "Alllah SWT" .

Prinsip mencerdaskan seperti yang dimaksud dalam perundag-undangan di atas, adalah upaya sepenuhnya ada di tangan para pendidik mahasiswa " dosen" . Olehnya dosen yang diberi tugas dengan segala kekurangan dan keterbatasan yang dimiliki, tentunya juga memiliki kemampuan dnn keahlian berupa kemampun professional dan kreaatifitas mengelola kelas anak didik menjadi kelas anak yang menyenangkan, mudah mencerna dan menerima asupan pengetahuan dari dosen pendidikinya.

Beberapa hasil penelitian menujukkan, bahwa adanya tingkat kebosanan dan kejenuanan anak didik dalam kelas karena ketidak mampuan pendidik mengelolala secara kreatif kelas menjadi hidup dan bersemangat.

Olehnya salah satu solusi, adalah paling tidak, ada upaya-uapaya kreatif, baik memakai alat peraga sederhana sampai yang moderen dan atau tanpa memakai alat peraga tetapi menyenangkan.

Disimpulkan bahwa perintah konstitusi dan perundng-undangan dalam upaya mencerdaskan anak didik tidak disebut secara teknis dan lilmitatif, Namun secara tersirat dimaknai, bhwa upaya pencerdasan anak tersebut menurut konsitusi dan perundanga-undangan adalah tetap dikehendaki, dengan mempercayakan dan menyerahkan sepenuhnya pada pendidik "dosen" yang bersangkutan dengan segala daya, upaya dan kemampuan "kreatifitas" .

Dari hasil penelitian yang dilakukan tentang pelaksanaan model/kreasi pembelajaran materi ilmu pengetahuan khususnya ilmu pengetahuan hukum khususnya di fakultas syariah dn hukum Universittas Islam Negeri Alauddin Makassar pada beberapa jurusan/prodi yang ada, dengan spesifik meamakai alat peraga, hanyalah pada beberapa bidang ilmu misalnya bidang ilmu falak "penenutuan waktu shalat dan hari-harri-hari besar umat Islam "Idul fitri dan Idul adha/idul qurban" serta penentuan arah shalat dan ataua arah kiblat masjid", begitupun pemakaian alat peraga dalam kegiatan peradilan semu.

Beberapa hal pengajaran dengan memakai alat peraga tersebut seperti yang disebut di atas, masihlah bersifat temporer, yakni satu atau atau dua kali dalam perkuliahan yang dilakukan sebagai tugas laboratorium.

Adapun model pengajaran yang sifatnya satu kesatuan dan tidak bersifat temporeri dengan bidang ajar yang dilakukan secara berkesinambngan setiap kali pertemun kuliah, hanyalah dilaakukan oleh dua prodi/jurusan yang ada, yakni prodi ilmu hukum (IH) dan prodi pidan dan ketatanegaraan (HPK) dengan beberapa mata kuliah tertentu yang brssentuhan dengan problem hukum dn sosial keseharian yang terjadi di masyarakat, yang setiap waktu mempunyai porsi pemberitaan di medi massa "harian fajar" yang paling tidak setiap pekan, ada peristiwa hukum, sosial dan 
kriminal, baik yang umum atau biasa maupun yang temporer.

Berita-berita hukum pidana, kriminal, dan sosial tersebut sangat bersentuhan dengan beberapa mata kuliah yang ada dalam kurikukum dua juruan/prodi tersebut. yakni prodi Ilmu Hukum (IH) dan prodi Hukum Pidana dan Ketatatnegaraaan Islam (HPK) dan ke dua prodi tersebut memiliki beberapa mata kuliah yang sama dalam kurikulumnya , misalnya mata kuliah. Hukum pidana,hukum acara pidana hukum perdata,hukum acara perdata, hukum tata negara, hukum acara mahkamah konstitusi hukum adminintarsi negara. Namun dalam peneletian ini peneliti hanya mengambil sampel pada prodi ilmu hukum pada fakultas syariah dan hukum UIN alauddin.

Adapun dua prodi lain dalam fakultas yang sama yakni, prodi Peradilan agama Islam dan prodi perban dingan mashab Islam. Dari hasil penelitian yang peneliti lakukan tidak ada satupun dosen yang melakukan model/kreasi mengajar memakai alat peraga berita-berita hukum, sosial dan kriminal pada koran "fajar".

Dari hasil penelitian menunjukkan bahwa dari dua prodi sebagai tempat pelaksanaan model/kreasi mengajar tersebut dan yang dosen yang melakukan model/kreasi tersebut hanyalah satu (1) orang dosen sebagai sampel dan satu (1) mata kuliah saja sebagai sampel saja dengan tiga (3) mata kuliah yang berbeda, yakni mata hukum pidana, hukum acara pidana dan sosiologi hukum yang telah berjalan dan berlangsung saat ini.

Hasilnya dalam pelaksanaanya penerapan model/kreasi tersebut tidak terdapat hambatan dan halangan dan tidak mengganggu hal lain, bahkan mendapat respon yang baik dan tanggapn balik yang menghendaki lebih dikembangkan pada semua mata kuliah yang relevan dilakukan untuk itu.

Adapun sikap dan ungkapan para mahasiswa terhadapa model/kreasi dengan pembelajaran kreatif dengan menghubungkan materi ajar dengan alat bantu beritaberita seputar hukum, sosial dan krinminologi di harian fajar. Penelitian yang dilakukan dengan menyebarkan selembar kuesioner yang dalamnya berisi pertanyaan-pertanyan.

Adapun isi pertanyaan itu, antara lain yakni:

(1). Apakah anda puas atau tidak puas terhadap model /kreasi dengan menampilkan kliping koran tentang berita-berita hukum, sosial dan kriminal dikoran harian fajar jawabannya dengan mencontreng

(a) Puas

(b) Tidak puas

Dari sampel dua kelas anak didik yang diajar dengan jumlah, mahasiswa 40 orang, maka 40 orang mahasiswa tersebut, atau pada umumnya atau $100 \%$ mengatakan atau dengan mencontreng dengan kata puas

Tabel 1 di bawah ini tentang respon (puas atau tidak puas )mahasiswa dalam kelas terhadap model/kreasi yang dilakukukan oleh Dosen mata kuliah hukum pidana dan sosologi hukum dengan memakai alat peraga guntingan media (koran 
fajar) yang memuat berita -berita dan peristiwa hukum, sosial dan kriminologi

Tabel 1

\begin{tabular}{|l|l|l|l|}
\hline No. & Respon puas & Jumlah mahasiswa & Prosentase \% \\
\hline 1 & Puas & 40 & $100 \%$ \\
\hline 2 & Tidak puas & 0 & $0 \%$ \\
\hline 3 & Jumla & 40 & $100 \%$ \\
\hline
\end{tabular}

Sumber : Data Angket April-Mei 2014

(2). Dari respon anda puas atau tidak puas di atas dengan model / kreasi dengan pelajaran hukum dengan metode/wadah dengan memakai, memperlihatkan dan mengkaitkannya dengan berita-berita hukum dari klipping guntingan koran harian fajar yang memuat peristiwa hukum yang akual dan dikaitkan dengan materi pembelajaran hukum pada hari materi pelajaran hukum hari itu dan apakah anda suka atau tidak suka?

(Jawabannya dengan mencontreng dengan memilih salah satu dari 2 (dua) pilihan jawaban, yakni:
(a) suka
(b) tidak suka

Dari sampel dua kelas anak didik yang diajar dengan jumlah, mahasiswa 40 orang, maka 40 orang mahasiswa tersebut , umumnya atau $100 \%$ mengatakan suka atau dengan mencontreng dengan kata suka.

Tabel 2 di bawah ini tentang respon (suka atau tidak suka)mahasiswa dalam kelas terhadap model/kreasi yang dilakukukan oleh Dosen mata kuliah hukum pidana dan sosologi hukum dengan memakai alat peraga guntingan koran fajar yang memuat berita -berita dan peristiwa hukum, sosial dan kriminologi.

Tabel 2

\begin{tabular}{|l|l|l|l|}
\hline No. & Respon & Jumlah mahasiswa & Prosentase (\%) \\
\hline 1 & Suka & 40 & $100 \%$ \\
\hline 2 & Tidak suka & 0 & $0 \%$ \\
\hline 3 & Jumlah & 40 & $100 \%$ \\
\hline
\end{tabular}

Sumber : Data Angket April-Mei 2014

(3) Dari pilihan suka atau tidak suka dan puas dan tidak puas, apakah saudara telah merasakan sesuatu yang bersifat menyenangkan atau tidak meyenangkan dengan dengan model/kreasi yang anda telah dapatkan tersebut?. Berilah tanda atau pilih/contreng.

(a) Menyenangkan

(b) Tidak menyenangkan 
Dari sampel dua kelas anak didik yang diajar dengan jumlah, mahasiswa 40 orang, maka 40 orang mahasiswa tersebut, umumnya atau $100 \%$ mengatakan menyenangkan atau dengan mencontreng dengan kata menyenangkan.

Tabel 3 di bawah ini tentang respon (menyenangkan atau tidak menyenangkan )mahasiswa dalam kelas terhadap model/kreasi yang dilakukukan oleh Dosen mata kuliah hukum pidana dan sosologi hukum dengan memakai alat peraga guntingan koran fajar yang memuat berita -berita dan peristiwa hukum, sosial dan kriminologi.

Tabel 3

\begin{tabular}{|l|l|l|l|}
\hline No. & Respon & $\begin{array}{l}\text { Jumlah } \\
\text { Mahasisiwa }\end{array}$ & Prosentase \% \\
\hline 1 & Menyenangkan & 40 & $100 \%$ \\
\hline 2 & Tidak menyenangkan & 0 & $0 \%$ \\
\hline 3 & Jumlah & 40 & $100 \%$ \\
\hline
\end{tabular}

Sumber : Data Angket April-Mei 2014

(4) Dari pilihan suka atau tidak suka dan puas dan tidak puas, menyenangkan atau tidak meyenangkan dengan dengan model/kreasi yang anda telah dapatkan tersebut. Apakah pula model/kreasi tersebut membuat anda mudah mengerti atau tidak mudah mengerti?. Berilah tanda atau pilih/contreng.

(a) Mudah di mengerti

(b) Tidak mudah dimengerti

Dari sampel dua kelas anak didik yang diajar dengan jumlah, mahasiswa 40 orang, maka 40 orang mahasiswa tersebut, umumnya atau $100 \%$ mengatakan mudah dimengerti atau dengan mencontreng dengan kata mudah dimengerti.

Tabel 4 di bawah ini tentang respon (mudah dimengerti atau tidak mudah dimengerti )mahasiswa dalam kelas terhadap model/kreasi yang dilakukukan oleh Dosen mata kuliah hukum pidana dan sosologi hukum dengan memakai alat peraga guntingan koran fajar yang memuat berita -berita dan peristiwa hukum, sosial dan kriminologi.

Tabel 4

\begin{tabular}{|l|l|l|l|}
\hline No. & Respon & $\begin{array}{l}\text { Jumlah } \\
\text { Mahasisiwa }\end{array}$ & Prosentase \% \\
\hline 1 & Mudah dimengerti & 40 & $100 \%$ \\
\hline 2 & Tidak mudah dimengerti & 0 & $0 \%$ \\
\hline 3 & Jumlah & 40 & $100 \%$ \\
\hline
\end{tabular}

Sumber : Data Angket April-Mei 2014

(5). Berilah alasan anda atau komentara aatau kesimpulan alasan atas masingmasing atau atas dua jawaban/contreng yang anda sudah tulis.

Dari sampel dua kelas anak didik yang diajar dengan jumlah mahasiswa 40 
orang, maka mahasiswa tersebut, atau umumnya atau $100 \%$ mengatakan suka, puas, menyenangkan akan model tersebut dan menghendaki agar semua mata kuliah yang lain dapat dilakukan hal yang sama

Tabel 5 di bawah ini tentang kesimpulan -kesimpulan yang dapat ditarik atas dua jawaban yang ditulis/contreng pada lembar soal yang telah disediiakan, pada prinsipnya ada dua (2) kesimpulan yang kaitannya tentang model/kreasi dosen dengan mata kuliah hukum pidana, sosiologi hukum dan kriminologi, dengan memakai alat peraga guntingan koran/media (haria fajar) yang berisi berita-berita hukum, yang hasilnya berupa saran, tindak lanjut atau rekomendasi

Tabel 5

\begin{tabular}{|l|l|l|l|}
\hline No. & Kesimpulan respon jumlah & Prosentase \% \\
\hline 1 & $\begin{array}{l}\text { Diteruskan dan direkomendasikan } \\
\text { model/kreasi tersebut }\end{array}$ & 40 & $100 \%$ \\
\hline 2 & $\begin{array}{l}\text { Tdak diteruskan dan tidak } \\
\text { direkomendasikan model/kreasi } \\
\text { tersebut }\end{array}$ & 0 & $0 \%$ \\
\hline 3 & Jumlah & 80 & $100 \%$ \\
\hline
\end{tabular}

Sumber : Data Angket April-Mei 2014

\section{KESIMPULAN}

1. Perintah konstitusi Negara dan perundang-undangan untuk mencerdaskan kehidupan warga dalam bidang ilmu pengetahuan dan teknologi serta meninggikan keiimanan dan ketaqwaan (IPTEK dan IMTAQ), khususnya bagi mereka yang mengikuti kegiatan pendidikan di perguruan tinggi, sudah sangat jelas, khususnya para pendidik di semua level pemdidikan, baik pada tingkat/level dasar sampa pada tingkat/level perguruan tinggi, khususnya di prioritaskan bagi mereka yang ditugaskan mendidik mahasiswa atau yang menyandang gelar dosen.

2. Perintah melaksanakan untuk pencerdasan dan pencerahan di Universitas Islam Negeri Alauddin Makassar khususnya di fakultas syariah dan hukum pada program studi ilmu hukum ditekankan pada peraturan akademik universitas Islam Negeri Alauddin Makassar dan terkristalisasi dalam visi dan misi universitas dan visi misi program studi ilmu hukum pada khususnya. Adapun dalam pelaksanaan sudah berjalan, namun masih belum terlihat secara signifikant model/kreasi yang kreatif dan mencerdaskan di antara sekian banyak pendidik "dosen" yang berpotensi kreatif, sehingga model/kreasi pencerdasan yang ada, barulah terbatas segelintir satu atau dua orang dosen di setiap fakultas atau prodi yang ada. Khususnya pada fakultas syariah dan hukum, barulah sebatas satu atau dua dosen pada dua (2) prodi yang ada, antara lain prodi ilmu hukum dan prodi hukum pidaa da 
ketatanegaraan Islam

3. Harian fajar sebagai sumber/alat/aas info-info hukum, menjadi sangat berarti dan penting dalam pengembangan pengajaran ilmu hukum pidana dalam kelas.

4. Bentuk model/kreasi pencerdasan yang ditemukan pada prodi ilmu hukum dan ketatanegaraan Islam, menimbulkan antusiasme mahasiswa dan respon yang sangat baik dan linier dengan perkembangan pemahaman yang meningkat akan suatu ilmu pengetahuan khususnya pemahaman ilmu hukum pidana, kriminologi dan sosiologi hukum.

\section{IMPLIKASI PENELITIAN}

Hasil penelitian ini, merekomendasikan kepada setiap dosen dalam lingkup UIN Alauddin Makassar dan khususnya pada fakultas syariah dan hukum, agar senantiasa kreatif dalam proses mengajar dalam kelas, paling tidak mengikuti model/kreasi yang mencerdaskan yang dilakukan oleh salah satu dosen pada prodi ilmu hukum dan salah satu dosen pada prodi hukum pidana dan ketatanegaran Islam.

\section{Daftar Pustaka}

Ahmd Ali, Menguak Tabir Hukum, Chandra Dipta, 1988.

Arief Budiman, Diskusi Pendidikan, TVRI, Jakarta, 2008.

Hermawan Kertawijaya, "Analisis Kepuasaan Konsumen", Ceramah Motivator Management, Hotel Clarion. Makassar, 2008.

Lili Rasyidi, I B Wyasa Putra, Hukum sebagi suatu sistem, Mandar Maju, Bandung, 2003.

Ngainun N, menjadi Guru Insfiratif, Pustaka Pelajar, Jogyakarta, 2011.

Rahman Getteng, Menuju Guru Profesional dan Beretika, Graha Guru, Jogjakarta, 2012.

Sugiyono, Memahami Penelitian Kualitatif, Alfabeta Bandung, 2009.

Suprihanto, Fungsi pendidikan, Gramedia, jakarta, 2003.

Simandjunak, Pengantar Kriminologi dan Patologi Sosial, Tarsito, Bandung, 1981.

Undang-undang No. 12 Tahun 2012 tentang Sistem Pendidikan Nasional, Harvarindo, Jakarta, 2012.

Undang-Undang No. 20 Tahun 2003, Tentang Sistem Pendidikan Nasional, Laksana Jogyakarta, 2003.

Biro Administarsi Akademik dan Kemahasiswaan UIN Alauddin, Kumpulan Peraturan akademik, Makassar 2011.

Harian Fajar, Fajar Group, Makassar, 2008-2014. 